\title{
Identification and Cultivar Reaction to Three New Races of the Spinach Downy Mildew Pathogen from the United States and Europe
}

\author{
B. M. Irish and J. C. Correll, Department of Plant Pathology, University of Arkansas, Fayetteville 72701; \\ S. T. Koike, University of California Cooperative Extension, Salinas 93901; J. Schafer, Schafer Agricultural \\ Services, Mt. Vernon, WA 98273; and T. E. Morelock, Department of Plant Pathology, University of Arkansas
}

\begin{abstract}
Irish, B. M., Correll, J. C., Koike, S. T., Schafer, J., and Morelock, T. E. 2003. Identification and cultivar reaction to three new races of the spinach downy mildew pathogen from the United States and Europe. Plant Dis. 87:567-572.

Since 1996, commercial spinach cultivars with resistance to four previously described races of Peronospora farinosa f. sp. spinaciae (races 1, 2, 3, and 4) were observed with high incidences of downy mildew both in California and Europe. Isolates of $P$. farinosa f. sp. spinaciae collected in California between 1997 and 2001, Arizona in 1999, and a single isolate collected in the Netherlands in 1996 were examined for their disease reaction on differential spinach cultivars and a set of commercial spinach cultivars. Disease reactions on the differential cultivars indicated the occurrence of three new races of $P$. farinosa $\mathrm{f}$. sp. spinaciae. Two newly identified races, designated race 5 (isolate CA1) and race 6 (isolate SP1), were detected in the United States. The isolate from the Netherlands also was distinct and designated race 7 (isolate JVN7). Some cultivars with resistance to races $1,2,3$, and 4 were susceptible to race 5 , whereas others were resistant, indicating that resistance to a given race may be governed by different genes (or alleles) depending on the source of resistance. A survey of races in California indicated that races 5 and 6 predominated. Although the majority of the cultivars examined were susceptible to race 6 based on the traditional qualitative cotyledon inoculation assay, significant quantitative differences in resistance to race 6 were observed using a true-leaf greenhouse screening procedure. Although more work is needed to confirm the results of the true-leaf assays, the quantitative resistance observed using this procedure appears to be race specific.
\end{abstract}

Spinach (Spinacia oleracea) is an important vegetable crop grown on more than 16,000 ha in the United States and is valued at approximately $\$ 184$ million annually (17). Major areas of production include California, Colorado, Texas, Arkansas, Oklahoma, and parts of the east coast (8). Downy mildew, or blue mold, caused by Peronospora farinosa (Fr.) Fr. f. sp. spinaciae Byford (1), is an economically important pathogen on spinach in most regions where the crop is grown. Prior to 1996, four races of the pathogen were known to occur in the United States and Europe (Table 1). Although major (qualitative) and minor (quantitative) gene resistance to the various downy mildew races has been identified in spinach (2$5,9,14,15)$, major gene resistance has been the type of resistance used almost exclusively to manage this disease (5). Screening for major gene resistance to $P$. farinosa f. sp. spinaciae typically has relied on a qualitative cotyledon greenhouse infection assay and has become the

Corresponding author: J. C. Correll

E-mail: jcorrell@uark.edu

Accepted for publication 23 December 2002.

Publication no. D-2003-0317-03R

(C) 2003 The American Phytopathological Society routine industry standard for evaluating resistance.

Beginning in 1996, cultivars with resistance to the four previously known races (races 1, 2, 3 and 4) of the pathogen were observed with high levels of disease in commercial fields in California and Europe. Consequently, work was initiated to document whether or not new races of the pathogen were present based on disease reactions on differential cultivars; a survey of prevalent races in California also was conducted. In addition, commercial cultivars were screened for qualitative and

Table 1. History of the occurrence of races of Peronospora farinosa f. sp. spinaciae

\begin{tabular}{llll}
\hline Race & Year $^{\mathbf{y}}$ & Location & Reference \\
\hline Race $1^{\mathrm{z}}$ & 1824 & U.S./Europe & 12,19 \\
Race 2 & 1958 & California & 22 \\
& 1958 & Europe & 20 \\
Race 3 & 1976 & Netherlands & 10 \\
& 1978 & California & 11,21 \\
Race 4 & 1982 & Texas & 14 \\
& 1990 & California & 6 \\
& 1991 & California & 2 \\
Race 5 & 1991 & Texas & 2 \\
& 1994 & Europe & 16 \\
Race 6 & 1996 & Colorado & J. Schafer, unpublished \\
Race 7 & 1997 & California & J. Schafer, unpublished \\
\hline
\end{tabular}

y Year the race of $P$. farinosa f. sp. spinaciae was observed or reported.

$\mathrm{z}$ The year the pathogen was observed and described and later assigned a race 1 designation. quantitative resistance to two new races (race 5 and 6) of the pathogen common in California.

\section{MATERIALS AND METHODS}

Planting and plant maintenance. Spinach seed (without fungicide treatment) was sown directly into Redi Earth Mix (ScottSierra, Marysville, $\mathrm{OH})$ in flats with 10 rows and 20 seed per row. Plants were grown in a greenhouse with temperatures ranging from 15 to $25^{\circ} \mathrm{C}$. Plants were watered daily and fertilized once a week beginning 7 days after planting with an allpurpose fertilizer (Peters 20/20/20).

For the race identification tests, spinach seedlings were grown as described above and inoculated with a sporangial suspension $\left(2.0\right.$ to $3.0 \times 10^{5}$ sporangia $\left./ \mathrm{ml}\right)$ collected from cv. Viroflay increase plants (described below). Seedlings (7 to 10 days old) were inoculated at the cotyledon stage, incubated at $100 \%$ relative humidity $(\mathrm{RH})$ and $20^{\circ} \mathrm{C}$ for $24 \mathrm{~h}$, and then incubated in the growth chamber as previously described. Six days after inoculation, plants were returned to the dew chamber maintained at $20^{\circ} \mathrm{C}$ and $100 \% \mathrm{RH}$ for 18 to $24 \mathrm{~h}$.

To quantify resistance to races 5 and 6 , cotyledons and the first set of true leaves on 2-week-old seedlings were inoculated. The first set of true leaves were approximately $2 \mathrm{~cm}$ long at the time of inoculation. Plants were inoculated with a sporangial suspension $\left(5.0 \times 10^{5}\right.$ sporangia/ml $)$ of either race 5 (isolate UMA1) or race 6 (isolate SP1) and incubated as earlier described. 
Inoculum preparation. Inoculum of the various isolates was recovered either from spinach leaves stored at $-20^{\circ} \mathrm{C}$ or from leaves collected directly from the field. Inoculations were conducted as previously described $(2,4)$. Briefly, leaves were placed into a flask containing chilled $\left(4^{\circ} \mathrm{C}\right)$ distilled water, shaken vigorously, and poured through two layers of cheesecloth to remove debris. To produce fresh inoculum, the spore suspension, which varied in initial concentration, was sprayed onto 10- to 14-day-old spinach seedlings of the susceptible cv. Viroflay grown as previously described. Inoculations were done using a diaphragm air compressor Model 80-2 (Badger Air Brush Co., Franklin Park, IL). The plants were incubated in a dew chamber maintained at $18^{\circ} \mathrm{C}$ and $100 \% \mathrm{RH}$ for $24 \mathrm{~h}$, and then incubated in a growth chamber maintained at $20^{\circ} \mathrm{C}$ with a 12 -h cycle of light and dark for 6 days. On the sixth day, the plants were returned to the dew chamber and maintained at $18^{\circ} \mathrm{C}$ and $100 \% \mathrm{RH}$ for 18 to $24 \mathrm{~h}$ to induce sporulation. The inoculum increase cycle on cv. Viroflay typically was performed twice for each isolate to produce sufficient fresh inoculum for further testing.

Race identification. Six isolates of $P$. farinosa f. sp. spinaciae were used in the initial study to determine if new races of the pathogen were present in the United States and Europe. The six isolates used for detailed characterization were selected based on preliminary data on disease reactions on several cultivars resistant to races 1, 2, 3, and 4. Isolates CA1 (race 5), CA1/1 (race 5), SP1 (race 6), and CA2 (race 6) were collected from different spinach fields in the Salinas Valley (Monterey County) of central California in 1997, 1997, 1998, and 1998, respectively. An isolate from Arizona, UMA1 (race 5) was collected from Yuma, AZ in 1999. An isolate from the Netherlands, JVN7 (race 7), was collected in 1996. All isolates were stored as infected plant material in a freezer at $-20^{\circ} \mathrm{C}$ until they could be processed and characterized.

The six isolates were inoculated onto two sets of differential spinach cultivars known to have different resistances to the various races (Table 2). One set of

Table 3. Number and race identification of isolates of Peronospora farinosa f. sp. spinaciae

\begin{tabular}{lcll}
\hline Race & Number of isolates & Host origin & Location $^{\mathbf{z}}$ \\
\hline Race 3 & 1 & $\ldots$ & Uvalde, TX \\
Race 4 & 1 & 5086 & Salinas, CA \\
Race 5 & 3 & Sharon 2801 & Salinas, CA \\
Race 5 & 1 & $\ldots$ & Desert \\
Race 5 & 1 & 5086 & Salinas, CA \\
Race 5 & 3 & Sharon 2801 & Salinas, CA \\
Race 5 & 1 & Sharon 2801 & Desert \\
Race 5 & 2 & Unipak 12 & Salinas, CA \\
Race 5 & 2 & Unipak 12 & Desert \\
Race 5 & 3 & Bossanova & Salinas, CA \\
Race 5 & 1 & Space & Salinas, CA \\
Race 5 & 1 & Previa & Desert \\
Race 5 & 1 & $\ldots$ & Colorado \\
Race 6 & 11 & Springfield & Salinas, CA \\
Race 6 & 3 & Nordic IV & Salinas, CA \\
Race 6 & 2 & Nordic IV & Desert \\
Race 6 & 1 & Spinnaker & Salinas, CA \\
Race 6 & 1 & Spinnaker & Desert \\
Race 6 & 2 & Unipak 12 & Salinas, CA \\
Race 6 & 1 & Unipak 12 & Desert \\
Race 6 & 1 & Farallon & Salinas, CA \\
Race 6 & 1 & Miguel & Salinas, CA \\
Race 6 & 1 & Olympia & Salinas, CA \\
Race 6 & 1 & Tyee & Salinas, CA \\
Race 6 & 1 & Whale & Salinas, CA \\
Race 6 & 1 & 5086 & Salinas, CA \\
Race 6 & 1 & 94675 & Santa Maria, CA \\
\hline
\end{tabular}

${ }^{\mathrm{z}}$ Desert locations include Imperial County, CA and Yuma, AZ sites.

Table 2. Disease reactions of differential spinach genotypes used to characterize races of Peronospora farinosa f. sp. spinaciae

\begin{tabular}{|c|c|c|c|c|c|c|c|}
\hline \multirow[b]{2}{*}{ Genotype $^{y}$} & \multirow[b]{2}{*}{ Resistance } & \multicolumn{6}{|c|}{$\operatorname{Race}^{x}$} \\
\hline & & CA1, race 5 & CA1/1, race 5 & UMA1, race 5 & SP1, race 6 & CA2, race 6 & JVN7, race 7 \\
\hline Viroflay & None & + & + & + & + & + & + \\
\hline $99 \times 95$ & 1,2 & + & + & + & + & + & + \\
\hline Califlay & $1,3,5$ & - & - & - & + & + & + \\
\hline Polka & $1,2,3,5$ & - & - & - & + & + & + \\
\hline Bolero & $1,2,3,4$ & + & + & + & + & + & + \\
\hline Whitney & $1,2,3,4$ & + & + & + & + & + & + \\
\hline Rushmore & $1,2,3,5$ & - & - & - & + & + & + \\
\hline Campania (SAS1) & $1,2,3,4,5,7$ & $\ldots$ & $-^{\mathrm{z}}$ & - & + & + & - \\
\hline Lion & $1,2,3,4,5,6,7$ & $\ldots$ & - & - & - & - & - \\
\hline St. Helens & $1,2,3,5$ & - & - & - & + & + & + \\
\hline NAKG1 (Winterreuzen) & None & $\ldots$ & $\ldots$ & + & + & $\ldots$ & + \\
\hline NAKG2 (Nores) & 1,2 & $\ldots$ & $\ldots$ & + & + & $\ldots$ & + \\
\hline NAKG3 (Califlay) & $1,3,5$ & $\ldots$ & $\ldots$ & - & + & $\ldots$ & + \\
\hline NAKG4 (Polka) & $1,2,3,5$ & $\ldots$ & $\ldots$ & - & + & $\ldots$ & + \\
\hline NAKG5 (Rushmore) & $1,3,4,5$ & $\ldots$ & $\ldots$ & - & + & $\ldots$ & + \\
\hline NAKG6 (Bolero) & $1,2,3,4$ & $\ldots$ & $\ldots$ & + & + & $\ldots$ & + \\
\hline NAKG7 (Spinnaker) & $1,2,3,4,5$ & $\ldots$ & $\ldots$ & - & + & $\ldots$ & + \\
\hline NAKG8 (Spicer) & $1,2,3,4$ & $\ldots$ & $\ldots$ & + & + & $\ldots$ & + \\
\hline NAKG9 (San Felix) & $1,2,3,4,5$ & $\ldots$ & $\ldots$ & - & + & $\ldots$ & + \\
\hline NAKG10 (Clermont) & $1,2,3,4$ & $\ldots$ & $\ldots$ & + & + & $\ldots$ & + \\
\hline NAKG11 (Lion) & $1,2,3,4,5,6,7$ & $\ldots$ & $\ldots$ & - & - & $\ldots$ & - \\
\hline NAKG12 (Scenic) & $1,2,3,4,5,7$ & $\ldots$ & $\ldots$ & $\ldots$ & + & $\ldots$ & $\ldots$ \\
\hline NAKG13 (El Dorado) & $1,2,3,4,5,7$ & $\ldots$ & $\ldots$ & - & \pm & $\ldots$ & - \\
\hline NAKG14 (Eagle) & $1,2,3,4 ?$ & $\ldots$ & $\ldots$ & + & \pm & $\ldots$ & \pm \\
\hline
\end{tabular}

${ }^{\mathrm{x}}$ Race designations were based on the disease reaction of the differential genotypes: + indicates that $>85 \%$ of the cotyledons showed evidence of infection and sporulation after 7 days and were considered susceptible; - indicates that $<15 \%$ of the cotyledons showed evidence of infection and sporulation after 7 days and were considered resistant; \pm indicates an intermediate reaction.

y Named or numbered genotypes. Parenthetical designations are alternative names or commercial cultivar names also used with the numbered genotypes.

${ }^{\mathrm{z}}$ In one of the tests, plants showed symptoms but no sporulation. 
differentials, some of which were previously used in race identification tests (2), included a number of open-pollinated and hybrid cultivars common to U.S. production. The second set of differentials included a standardized set of material recently assembled for testing of resistance in Europe (designated NAKG) (Table 2). Isolates UMA1 (race 5), SP1 (race 6), and JVN7 (race 7) also were used to screen a collection of commercial cultivars for their susceptibility to the three new races.

To document the occurrence and distribution of the various races, 49 additional isolates were collected during the course of the study and characterized for their race identity. The isolates were collected from commercial spinach fields in California, Arizona, or Texas between 1999 and 2001. Fields with downy mildew were identified by various extension and field personnel during the course of the collections. Approximately 50 spinach leaves showing evidence of sporulation of the pathogen were collected and stored at either $4^{\circ} \mathrm{C}$ or $-20^{\circ} \mathrm{C}$ until processed. Isolates collected as part of the survey were only inoculated to the U.S. set of differentials.

For race identification, cotyledons were evaluated qualitatively for sporulation of the pathogen 18 to $24 \mathrm{~h}$ after the dew chamber treatment to induce sporulation. Any genotype with sporulation on $>85 \%$ of the total number of cotyledons was considered susceptible, whereas any genotype with sporulation on $<15 \%$ of the cotyledons was considered resistant, as previously described (2). Genotypes with intermediate reactions also were recorded.

The race identification experiments were set up as a completely randomized design with three replications. Each isolate was tested a minimum of four times on both sets of differentials. The isolates examined as part of the survey were inoculated onto the differentials only once.

Quantitative resistance to race 5 and race 6. To quantify resistance to race 5 and race 6 , both the cotyledons and the true leaves were evaluated for disease reactions. After sporulation was induced, each cotyledon was scored for the presence or absence of sporulation as previously described. The true leaves also were evaluated on a scale of 0 to 4 based on the percentage of leaf area with symptoms and sporulating lesions, where $0=$ no signs or symptoms of infection, $1=1$ to $25 \%, 2=26$ to $50 \%, 3=$ 51 to $75 \%$, and $4=>75 \%$ of the leaf area showing sporulation and symptoms.

The experimental design for assessing quantitative reactions was set up as a completely randomized design with four replications. The race 6 quantitative evaluation test was conducted twice. The mean disease ratings were statistically compared using analysis of variance followed by a least significant difference means separation test $(P=0.05)$ with the statistical analysis program SAS (version 7.0; SAS
Institute Inc. Cary, NC). The same experimental design was used to assess quantitative disease reactions to race 5 and race 6 among a collection of commercial cultivars.

\section{RESULTS}

Race identification. Three new races, designated race 5, 6, and 7, of $P$. farinosa $\mathrm{f}$. sp. spinaciae were identified among the original six isolates selected for testing based on disease reactions on a set of differential spinach cultivars (Table 2). Three isolates (CA1, CA1/1, and UMA1) were identified as race 5, two isolates (SP1 and CA2) as race 6, and one isolate (JVN7) as race 7 . Isolates $\mathrm{CA} 1, \mathrm{CA} 1 / 1, \mathrm{CA} 2$, and SP1 were recovered in the Salinas Valley in California, UMA1 from Arizona, and JVN7 from the Netherlands.

Nine of the differential cultivars tested were susceptible to all three new races, including Viroflay and Winterreuzen, which are considered to be universal susceptible cultivars because they contain no known resistance genes (Table 2). Many of the differentials were resistant to race 5 but susceptible to race 6 and 7 . Only one of the differential cultivars tested (Lion) was resistant to all three new races. Also, the only differential cultivar tested that could distinguish race 6 and race 7 was Campania, which was susceptible to race 6 but resistant to race 7 .

A total of 49 isolates of the downy mildew pathogen were recovered from commercial spinach fields between 1997 and 2001 (Table 3). A single isolate from Texas and a single isolate from California were identified as races 3 and 4, respectively. A total of 19 of the field isolates were identified as race 5 and 28 isolates were identified as race 6 . Race 7 was not identified in the United States.

In addition to the differential spinach cultivars tested, 43 additional commercial spinach cultivars were screened for their susceptibility to the three newly identified races (Table 4). Nineteen cultivars were susceptible to all three races, whereas four

Table 4. Qualitative disease reactions on commercial spinach lines inoculated with three newlyidentified races of Peronospora farinosa f. sp. spinaciae based on a cotyledon assay

\begin{tabular}{|c|c|c|c|c|}
\hline \multirow[b]{2}{*}{ Genotype } & \multirow[b]{2}{*}{ Resistance } & \multicolumn{3}{|c|}{ Disease reactions $^{\mathrm{z}}$} \\
\hline & & Race 5 & Race 6 & Race 7 \\
\hline Bolero & $1,2,3,4$ & + & + & + \\
\hline Bossanova & $1,2,3,4$ & + & + & + \\
\hline Bouquet & 1,2 & + & + & + \\
\hline Catatlina & $1,2,3,4$ & + & + & + \\
\hline Clermont & $1,2,3,4$ & + & + & + \\
\hline Miguel & $1,2,3,4$ & + & + & + \\
\hline Polydane & $1,2,3,4$ & + & + & + \\
\hline Poncho & $1,2,3,4$ & + & + & + \\
\hline Sombrero & $1,2,3,4$ & + & + & + \\
\hline Sprite & $1,2,3,4$ & + & + & + \\
\hline Teton & $1,2,3,4$ & + & + & + \\
\hline Unipack 12 (Ballet) & $1,2,3,4$ & + & + & + \\
\hline Unipack 131 (Lambada) & $1,2,3,4$ & + & + & + \\
\hline Unipack 144 (Santana) & $1,2,3,4$ & + & + & + \\
\hline Unipack 151 (Allegro) & $1,2,3,4$ & + & + & + \\
\hline Whitney & $1,2,3,4$ & + & + & + \\
\hline 961098 & $1,2,3,4$ & + & + & + \\
\hline 961102 & $1,2,3,4$ & + & + & + \\
\hline 961145 & $1,2,3,4$ & + & + & + \\
\hline Avanti & $1,2,3,4,5$ & - & + & + \\
\hline CXF3665 & $1,3,4,5$ & - & + & + \\
\hline CXF94675 & $1,3,4,5$ & _- & + & + \\
\hline Hydra & $1,2,3,4,5$ & - & + & + \\
\hline Kerdion & $1,2,3,4,5$ & - & + & + \\
\hline Nordic IV & $1,2,3,4,5$ & - & + & + \\
\hline Rushmore & $1,3,4,5$ & - & + & + \\
\hline Shasta & $1,2,3,5$ & _- & + & + \\
\hline Space & $1,2,3,5$ & - & + & + \\
\hline Spicer & $1,2,3,4$ & + & + & + \\
\hline Spinnaker & $1,2,3,4,5$ & - & + & + \\
\hline Springfield & $1,2,3,4,5$ & - & + & + \\
\hline St. Helens & $1,2,3,5$ & - & + & + \\
\hline Tyee - N & $1,3,5$ & - & + & + \\
\hline Ark-TO & $1,3,5$ & _- & \pm & \pm \\
\hline Wolter & $1,2,3,5$ & - & + & + \\
\hline 961135 & $?$ & _- & + & + \\
\hline Rebris & $?$ & + & + & \pm \\
\hline LD991020 (Cezanne) & $1,2,3,4,5,6,7$ & - & - & - \\
\hline LD991021 (Van Gogh) & $1,2,3,4,5,6,7$ & _- & - & - \\
\hline LD991022 (Monet) & $1,2,3,4,5,6,7$ & - & - & - \\
\hline Dolphin & $1,2,3,4,5,6,7$ & _- & - & - \\
\hline
\end{tabular}

${ }^{z}$ Disease reactions were based on the percentage of cotyledons infected: + indicates $>85 \%$ infected, - indicates $<15 \%$ infected, and \pm indicates an intermediate reaction. 
were resistant to all three. The cultivars resistant to all three originated from breeding programs initiated after the appearance of the new races. Interestingly, although 18 released cultivars with resistance to races 1, 2, 3 and 4 were susceptible to the newly described race 5 , some previously released cultivars with resistance to race $1,2,3$, and 4 were resistant to race 5 . Most of the commercial cultivars tested were susceptible to races 6 and 7 .

Quantifying resistance to races 5 and 6. In two independent experiments, all of the spinach genotypes except cv. Lion were susceptible to race 6 based on the traditional cotyledon infection assay, which has become an industry standard. However, scoring for disease severity on true leaves clearly indicated that there was a differential resistance response (Table 5). Significant differences in disease ratings were observed among the differential cultivars in both tests. An analysis of variance test indicated a significant treatment (cultivar) effect at $P<0.0001$. Although there was some variation in the absolute ratings between the two tests, the overall relative susceptibility ranking of the cultivars remained consistent between the two tests. For example, cvs. Viroflay and Winterreuzen and others were susceptible at the cotyledon stage and highly susceptible at the true-leaf stage, whereas eight cultivars (i.e., Spinnaker through SG6207) were susceptible at the cotyledon stage but moderately resistant at the true-leaf stage.
Based on the true leaf assay, quantitative differences in susceptibility also were observed among the commercial cultivars tested (Table 6). An analysis of variance test indicated a significant treatment (cultivar) effect at $P<0.0001$. However, for the cultivars considered susceptible to both races 5 and 6 based on the cotyledon assay, differences in susceptibility on true leaves were much more evident with race 6 . For example, a number of cultivars (i.e., F380, 424, and Fall Green) that were susceptible to race 5 and 6 in the cotyledon assay were considered highly susceptible to race 5 in the true leaf assay, but moderately resistant to race 6 in the true leaf assay (Table 6).

\section{DISCUSSION}

A standard nomenclature for designating races of the spinach downy mildew pathogen, $P$. farinosa f. sp. spinaciae, is important for seed companies to release and promote cultivars with accurate documentation of the downy mildew resistance they posses. Three new races of $P$. farinosa $\mathrm{f}$. sp. spinaciae, designated races 5,6 , and 7 , were identified in the current study based on disease reactions on two sets of differential spinach cultivars. Isolates of races 5 and 6 were recovered from spinach fields in California and Arizona. The single isolate examined from the Netherlands was unique and designated race 7 . Race 7 was not identified among the isolates collected from the United States. A survey of isolates indicated that 48 of the 49 isolates examined from the Salinas Valley of

Table 5. Quantitative differences in resistance to race 6 of Peronospora farinosa f. sp. spinaciae

\begin{tabular}{|c|c|c|c|c|c|c|}
\hline \multirow[b]{2}{*}{ Cultivar } & \multirow[b]{2}{*}{ NAKG ${ }^{\mathbf{y}}$} & \multicolumn{2}{|c|}{ Cotyledons $^{w}$} & \multicolumn{2}{|c|}{ True leaves $^{x}$} & \multirow[b]{2}{*}{$\operatorname{Rank}^{\mathbf{z}}$} \\
\hline & & Test 1 & Test 2 & Test 1 & Test 2 & \\
\hline Winterreuzen & NAKG1 & + & + & $4.0 \mathrm{a}$ & $3.9 \mathrm{a}$ & HS \\
\hline Clermont & NAKG10 & + & + & $4.0 \mathrm{a}$ & $3.8 \mathrm{a}$ & HS \\
\hline Viroflay & $\ldots$ & + & + & $4.0 \mathrm{a}$ & $3.7 \mathrm{a}$ & HS \\
\hline Spicer & NAKG8 & + & + & $4.0 \mathrm{a}$ & $3.7 \mathrm{a}$ & HS \\
\hline Whitney & $\ldots$ & + & + & $3.1 \mathrm{~cd}$ & $3.0 \mathrm{~b}$ & HS \\
\hline Bolero & $\ldots$ & + & + & $3.4 \mathrm{ab}$ & $1.3 \mathrm{c}$ & $\mathrm{S}$ \\
\hline Bolero & NAKG6 & + & + & $2.1 \mathrm{de}$ & $1.3 \mathrm{c}$ & $\mathrm{S}$ \\
\hline Califlay & $\ldots$ & + & + & $2.6 \mathrm{~cd}$ & $1.1 \mathrm{~cd}$ & $\mathrm{~S}$ \\
\hline Nordic IV (SanFelix) & NAKG9 & + & + & $2.0 \mathrm{def}$ & $1.0 \mathrm{~cd}$ & $\mathrm{~S}$ \\
\hline Califlay & NAKG3 & + & + & $2.6 \mathrm{~cd}$ & $1.0 \mathrm{~cd}$ & $\mathrm{~S}$ \\
\hline Rushmore & $\ldots$ & + & + & $1.6 \mathrm{efg}$ & $1.0 \mathrm{~d}$ & $\mathrm{~S}$ \\
\hline Campania & $\ldots$ & + & + & $2.8 \mathrm{bc}$ & $0.9 \mathrm{de}$ & $\mathrm{S}$ \\
\hline Spinnaker & NAKG7 & + & + & $1.1 \mathrm{gh}$ & 0.7 ef & MR \\
\hline \multirow[t]{2}{*}{ Rushmore } & NAKG5 & + & + & $1.6 \mathrm{efg}$ & $0.5 \mathrm{fg}$ & MR \\
\hline & NAKG14 & + & + & $1.0 \mathrm{gh}$ & $0.5 \mathrm{fg}$ & MR \\
\hline Polka & $\ldots$ & + & + & $0.9 \mathrm{gh}$ & $0.5 \mathrm{fg}$ & MR \\
\hline Nores & NAKG2 & + & + & $1.4 \mathrm{fgh}$ & $0.5 \mathrm{fg}$ & MR \\
\hline Polka & NAKG4 & + & + & $1.0 \mathrm{gh}$ & $0.4 \mathrm{fg}$ & MR \\
\hline $99 \times 95$ & $\ldots$ & + & + & $0.9 \mathrm{~h}$ & $0.3 \mathrm{gh}$ & MR \\
\hline SG6207 (El Dorado) & NAKG13 & $\pm(61)$ & $\pm(27)$ & $0.1 \mathrm{i}$ & $0.1 \mathrm{hi}$ & MR \\
\hline Lion & $\ldots$ & - & - & $0.0 \mathrm{i}$ & $0.0 \mathrm{i}$ & $\mathrm{R}$ \\
\hline
\end{tabular}

$\bar{w}+$ Indicates $>85 \%$ of cotyledons were susceptible, - indicates $<15 \%$ of the seedlings showed evidence of infection and sporulation after 7 days, and \pm indicates an intermediate reaction. Numbers in parentheses indicate percentage of cotyledons that were susceptible.

$\mathrm{x}$ True leaves were rated on a scale of 0 to 4 , where $0=$ no symptoms, $1=1$ to $25 \%, 2=26$ to $50 \%, 3$ $=51$ to $75 \%$, and $4=76$ to $100 \%$ disease. Numbers followed by the same letter within a column are not significantly different from one another $(P=0.05)$.

y European germ plasm source.

${ }^{\mathrm{z}}$ Disease reaction categories: $\mathrm{HS}=$ highly susceptible, $\mathrm{S}=$ susceptible, $\mathrm{MR}=$ moderately resistant, and $\mathrm{R}=$ resistant (or immune).

California and the desert growing regions of California and Arizona were either race 5 or race 6 , indicating a widespread distribution of these two new races in these regions. Although populations of $P$. farinosa f. sp. spinaciae were not sampled, field observations of downy mildew on cultivars being grown in Europe indicate that race 5 and race 7 predominate (J. Schafer, unpublished data).

Historically, screening for downy mildew resistance has relied on a qualitative disease assessment on the cotyledons of spinach seedlings. The absence of symptoms and sporulation indicated, albeit often presumptively, that a given genotype had resistance governed by a major (qualitative) resistance gene (5). One study, however, indicated that quantitative resistance was evident in some genotypes, even on cotyledons, to race 3 of $P$. farinosa $\mathrm{f}$. sp. spinaciae (2). When commercial breeders screen spinach germplasm to identify resistance to a new race of the downy mildew pathogen, the resistance is incorporated either into open pollinated cultivars or, more often, into hybrids. Consequently, the resistance used to a particular race by the various seed companies may not necessarily be associated with the same resistance gene (i.e., the resistance may not be allelic). This scenario was apparently the case for spinach cultivars with resistance to race 5. Although many of the spinach cultivars grown in California had resistance to races $1,2,3$, and 4 , some of these cultivars proved to be susceptible to race 5 while others proved to be resistant. Examining the parentage of these cultivars, it was apparent that there were either two different genes (or alleles) from different sources governing resistance to races 1 and 3 , one of which imparted resistance to race 5 , or that the source of resistance to races 1 and 3 was closely linked to the resistance gene for race 5 resistance (J. C. Correll, unpublished data). This alternate gene or allele (or linked resistance gene) appeared to be present in some of the cultivars evaluated and was effective against race 5 .

The appearance of race 6 in California was particularly problematic in that none of the commercial spinach cultivars evaluated displayed any qualitative resistance to this race at the time this new race appeared. All commercial cultivars were rated as susceptible to race 6 based on the cotyledon infection assay. However, field observations indicated that the cultivars considered susceptible to race 6 based on the greenhouse cotyledon assay exhibited quantitative differences in resistance to downy mildew under field conditions ( $\mathrm{J}$. Schafer and J. C. Correll, unpublished data). Consequently, a greenhouse true-leaf assay was developed to evaluate quantitative differences in susceptibility by inoculation of true leaves. These results clearly indicated significant quantitative differences in resistance among cultivars. 
Although the correlation between greenhouse observations of quantitative resistance and field reactions still needs to be evaluated further, field observations to date have been consistent with the greenhouse tests. Also of interest, the original male and female inbred parents of one particular hybrid were susceptible to race 6 in a cotyledon assay, whereas the hybrid itself was intermediate in its reaction and showed a substantially higher level of resistance at the cotyledon stage than either of the original parents. Thus, little is known of the actual genetic control of resistance to $P$. farinosa f. sp. spinaciae.

Only four races of the downy mildew pathogen were described between 1884 and $1995(5,8)$. Thus, it is surprising that three

Table 6. Disease reactions of commercial spinach cultivars inoculated with race 5 and race 6 of Peronospora farinosa f. sp. spinaciae ${ }^{\mathrm{y}}$

\begin{tabular}{|c|c|c|c|c|}
\hline \multirow[b]{2}{*}{ Cultivar $^{\mathrm{z}}$} & \multicolumn{2}{|c|}{ Race 5} & \multicolumn{2}{|c|}{ Race 6} \\
\hline & Cotyledons & True leaves & Cotyledons & True leaves \\
\hline Winterreuzen & + & 4.0 & + & 4.0 \\
\hline Viroflay & + & 4.0 & + & 4.0 \\
\hline Clermont & + & 4.0 & + & 4.0 \\
\hline Unipak 131 & + & 4.0 & + & 3.9 \\
\hline Spicer & + & 4.0 & + & 3.7 \\
\hline Sprite & + & 4.0 & + & 3.7 \\
\hline Unipak 151 & + & 4.0 & + & 3.4 \\
\hline Whitney & + & 4.0 & + & 3.0 \\
\hline Bossanova & + & 4.0 & + & 2.5 \\
\hline 961098 & + & 4.0 & + & 2.1 \\
\hline Polydane & + & 3.7 & + & 1.8 \\
\hline Bolero & + & 4.0 & + & 1.7 \\
\hline Teton & + & 3.8 & + & 1.7 \\
\hline Unipak 12 & + & 4.0 & + & 1.6 \\
\hline Rushmore & - & 0.0 & + & 1.6 \\
\hline Poncho & + & 4.0 & + & 1.5 \\
\hline 961145 (Caster) & - & 3.6 & + & 1.4 \\
\hline Nordic IV & - & 0.0 & + & 1.4 \\
\hline Califlay & _- & 0.0 & + & 1.3 \\
\hline 961102 & - & 0.8 & + & 1.2 \\
\hline CXF94684 & - & 0.0 & + & 1.2 \\
\hline Sombrero & + & 3.9 & + & 1.0 \\
\hline Unipak 144 & - & 0.0 & + & 1.0 \\
\hline $91-415$ & $\ldots$ & $\ldots$ & + & 0.9 \\
\hline Bolero & + & 3.9 & + & 0.8 \\
\hline Avanti & - & 0.0 & + & 0.8 \\
\hline F380 & + & 3.7 & + & 0.8 \\
\hline Hydra & - & 0.0 & + & 0.7 \\
\hline Kerdion & _- & 0.0 & + & 0.7 \\
\hline Spinnaker* & - & 0.0 & + & 0.7 \\
\hline Springfield & - & 0.0 & + & 0.6 \\
\hline CXF3665 & - & 0.0 & + & 0.6 \\
\hline Catalina & + & 2.8 & + & 0.6 \\
\hline 961135 & - & 0.0 & + & 0.5 \\
\hline Fall Green & + & 3.9 & + & 0.5 \\
\hline Polka & - & 0.0 & + & 0.5 \\
\hline Miguel & + & 3.8 & + & 0.5 \\
\hline 424 & + & 3.8 & + & 0.4 \\
\hline $88-212$ & $\ldots$ & $\ldots$ & + & 0.4 \\
\hline $99 \times 95$ & $\ldots$ & $\ldots$ & + & 0.3 \\
\hline Shasta & - & 0.0 & + & 0.3 \\
\hline Space & - & 0.0 & + & 0.2 \\
\hline Wolter & - & 0.0 & + & 0.2 \\
\hline Spinnaker & - & 0.0 & + & 0.1 \\
\hline Bouquet & + & 2.7 & + & 0.1 \\
\hline Ark-TO & - & 0.0 & \pm & 0.0 \\
\hline LD991020 (Cezanne) & - & 0.0 & + & 0.0 \\
\hline LD991021 (Van Gogh) & - & 0.0 & + & 0.0 \\
\hline LD991022 (Monet) & - & 0.0 & + & 0.0 \\
\hline Rebris & + & 2.3 & + & 0.0 \\
\hline Whale & - & 0.0 & + & 0.0 \\
\hline Eagle & \pm & 0.0 & + & 0.0 \\
\hline Dolphin & - & 0.0 & - & 0.0 \\
\hline Lion & - & 0.0 & - & 0.0 \\
\hline Lion* & - & 0.0 & - & 0.0 \\
\hline $\operatorname{LSD}(P=0.05)$ & $\ldots$ & $\ldots$ & $\ldots$ & 0.7 \\
\hline
\end{tabular}

${ }^{y}$ Cotyledons: + indicates $>85 \%$ of the seedlings showed evidence of infection and sporulation after 7 days, - indicates $<15 \%$ of the seedlings showed evidence of infection and sporulation after 7 days, and \pm indicates an intermediate reaction. True leaves were rated on a scale of 0 to 4 , where $0=$ no symptoms, $1=1$ to $25 \%, 2=26$ to $50 \%, 3=51$ to $75 \%$, and $4=76$ to $100 \%$ disease.

${ }^{z}$ Cultivars: * indicates seed coat was removed prior to testing. LSD $=$ least significant difference.

new races were detected in such a relatively short time. The mechanism by which these new races developed and were distributed is not known. However, there are several variables which could have contributed to the appearance of several new races in such a short period of time. Spinach acreage in California has increased significantly in recent years due to expanded markets, such as salad mixes and washed and packaged spinach. As a result, spinach typically is being grown yearround in California. Furthermore, production of "baby leaf" and "clip" spinach has used exceptionally high plant densities (9 to $18 \mathrm{million}$ seed/acre versus 6 to $9 \mathrm{mil}-$ lion seed/acre under conventional practices). Thus, year-round production, the use of downy mildew-resistant cultivars, and high plant densities all could be contributing factors, increasing the selection pressure on the pathogen population. Another mitigating factor could be weather, particularly the unusual weather patterns associated with El Niño and La Niña. The year races 5 and 6 became widespread in California (1998) was an El Niño year. The average statewide precipitation was 85.3 $\mathrm{cm}$ and ranked as the wettest year since 1895 according to the National Climatic Data Center website. These prolonged periods of moisture were very conducive for downy mildew infection and may have greatly increased pathogen populations. In addition, oospores of $P$. farinosa f. sp. spinaciae can be seedborne and could potentially introduce new races into production areas (13).

Future research efforts on downy mildew will need to focus on monitoring and characterizing new races of the pathogen. Most commercial spinach cultivars with different resistance genes are hybrids; therefore, it is important for the long term that a set of open-pollinated isogenic differentials be developed that contain different resistance genes. In addition, breeding efforts should continue to evaluate and utilize quantitative resistance to this important disease.

\section{ACKNOWLEDGMENTS}

We thank, for their support, the California Spinach Research Committee and its industry supporters.

\section{LITERATURE CITED}

1. Brandenberger, L. P., Correll, J. C., and Morelock, T. E. 1991. Nomenclature of the downy mildew fungus on spinach. Mycotaxon 41:157-160.

2. Brandenberger, L. P., Correll, J. C., Morelock, T. E., and McNew, R. W. 1991. Identification of and cultivar reactions to a new race (race 4) of Peronospora farinosa f. sp. spinaciae on spinach in the United States. Plant Dis. 75:630-634.

3. Brandenberger, L. P., Correll, J. C., Morelock, T. E., and McNew, R. W. 1994. Characterization of resistance of spinach to the white rust (Albugo occidentalis) and downy mildew (Peronospora farinosa f. sp. spinaciae). Phytopathology 84:431-437. 
4. Brandenberger, L. P., Morelock, T. E., and Correll, J. C. 1992. Evaluation of spinach germplasm for resistance to a new race (race 4) of Peronospora farinosa f. sp. spinaciae. HortScience 27:1118-1119.

5. Correll. J. C. 1998. Review of the biology of Peronospora farinosa f. sp. spinaciae. In: Crop Protection Compendium. CAB International, Agriculture Biosciences, Wallingford, UK.

6. Correll, J. C., Koike, S. T., Brandenberger, L. P., Black, M. C., and Morelock, T. E. 1990. A new race of downy mildew threatens spinach. Calif. Agric. 44:14-15.

7. Correll, J. C., Koike, S. T., Schafer, J., Anders, J. M., Irish, B. M., and Morelock, T. E. 1998. Two new races of the downy mildew pathogen (Peronospora farinosa f. sp. spinaciae) of spinach in the United States. (Abstr.) Phytopathology 88:S19.

8. Correll, J. C., Morelock, T. E., Black, M. C., Koike, S. T., Brandenberger, L. P., and Dainello, F. J. 1994. Economically important diseases of spinach. Plant Dis. 78:653- 660.

9. Correll, J. C., Morelock, T. E., and Koike, S. T. 1998. Screening of USDA spinach germ- plasm to two new races of the downy mildew pathogen (Peronospora farinosa f. sp. spinaciae). Leafy Vegetable Conf. Atlantic City, NJ.

10. Eenink, A. H. 1976. Linkage in Spinacia oleracea $\mathrm{L}$. of two race-specific genes for resistance to downy mildew Peronospora farinosa f. sp. spinaciae, Byford. Euphytica 25:713-715.

11. Greathead, A. 1980. Spinach mildew fought with breeding and chemicals. West. Grower Shipper 51:38-39.

12. Greville, R. K. 1824. Flora Edinensis. Blackwood \& Strand, London.

13. Inaba, T., Takahashi, K., and Morinaka, T. 1983. Seed transmission of spinach downy mildew. Plant Dis. 67:1139-1141.

14. Jones, R. K., and Dainello, F. J. 1982. Occurrence of race 3 of Peronospora effusa on spinach in Texas and identification of sources of resistance. Plant Dis. 66:1078-1079.

15. Koike, S. T., Smith, R. F., and Schulbach, K. F. 1992. Resistant cultivars, fungicides combat downy mildew of spinach. Calif. Agric. 46:29-31.
16. Lorenzini, G., and Nali, C. 1994. A new race (race 4) of spinach downy mildew in Italy. Plant Dis. 78:208.

17. Lucier, G., ed. 2000. Vegetables and Specialties Situation: An Outlook Report. Commodity Economics Division, Econ. Res. Serv. U. S. Dep. Agric. Washington, D.C.

18. Nali, C. 1998. A novel threat for spinach in Italy: a new race of downy mildew. Adv. Hortic. Sci. 12:179-182.

19. Satou, M., Sugiura, T., Ohsaki, R., Honda, N., Horiuchi, S., and Yamauchi, N. 2002. A new race of spinach downy mildew in Japan. J. Gen. Plant Pathol. 68:49-51.

20. Shimazaki, Y. 1990. Appearance of a new race 4 of downy mildew of spinach. Ann. Phytopathol. Soc. Jpn. 56:95.

21. Smith, P. G., Webb, R. E., Millett, A. M., and Luhn, C. H. 1961. Downy mildew on spinach. Calif. Agric. 15:5.

22. Smith, W. G. 1885. Disease of spinach, Peronospora effusa Grev. Gard. Chron. 23:480.

23. Zink, F. W., and Smith, P. G. 1958. A second physiologic race of spinach downy mildew. Plant Dis. Rep. 42:818. 